\title{
The Conflictual Theory of Law
}

\section{A Pragmatist Conception of Laws as Social Institutions}

\author{
Julius M. Rogenhofer \\ PhD Candidate, Department of Sociology, Faculty of Human, Social and \\ Political Science, University of Cambridge, Cambridge, UK \\ jmr217@cam.ac.uk
}

\begin{abstract}
This article introduces the conflictual theory of law as a new way of understanding laws as struggles over meaning, in which actors create and circulate social knowledge to justify their interpretation of rights. The theory addresses law-production processes and underlying knowledge/power constructs, for example, in legislative deliberations and interactions between politicians and the media. It shares pragmatist commitments to a highly participative version of democracy, attained through the active involvement of all members of society in democratic processes and rejects claims of universally applicable legal "truths" in favour of the constant (re)negotiation of laws between members immediately affected by a law. Pragmatism's antifoundationalism challenges the dualism between citizens and non-citizens, facilitating the inclusion of the latter in legislative deliberations.
\end{abstract}

\section{Keywords}

pragmatism - the conflictual theory of law - human rights - irregular migrants - law making

Despite the global human rights imagination's ongoing crisis (Hopgood 2013), its universalist justification for rights remains firmly entrenched in the institutional self-understanding of legal systems in many of the world's liberal democracies. In a particularly stark example, the Basic Law of the Federal Republic of Germany (Basic Law) mirrors the Universal Declaration of Human Rights (UDHR) in its commitment to 'inviolable and inalienable human rights as the 
basis of every community, of peace and of justice in the world' (Article 1(2)). This natural law conception of rights as fundamental and a-priori has been equated with Germany's entry into the community of Western democracies (Fraenkel 2011, 90) and to the origin of the German state (Rolin 2005). Yet liberalism's ahistorical and undifferentiated justifications, of what are undeniably important principles for the protection of human life and dignity, are unable to account for the pluralism intrinsic to social histories and human experiences.

The experiences of irregular migrants ${ }^{1}$ exemplify the inadequacy of universalist conceptions of rights and their safeguarding by legal regimes. Irregular migrants are typically confronted with insufficient human rights safeguards, both in their countries of origin and throughout their migration trajectory. Allegedly universalistic rights remain dependent on their recognition in law and enforcement by nation states and are, thus, contingent on citizenship of a rights protecting state or on a state's decision to protect the human rights of certain groups of non-citizens. The precariousness and vulnerability encountered by irregular migrants, even within the legal regime of their host-country, often coincides with restrictions on employment, constant threats of deportation, restrictions on mobility and, hence, highly conditional access to human rights protection. An absence of citizenship rights in the host-country further undermines each irregular migrant's political voice and entrenches their subordinated status within the host-community. As such, universalistic justifications have left irregular migrants and other typically marginalised actors unable to articulate human rights claims or to define the types of legal recognition they seek within their (new) communities. The figure of the irregular migrant will continue to accompany us throughout this article, in order to illustrate the practical implications of the arguments formulated herein.

In order to counteract the universalist justification for rights intrinsic to natural law theory and the liberal paradigm, this article offers a new theorisation of laws as social struggles over meaning, in which socio-political actors create and circulate social knowledge both to justify their interpretation of legal rights and to institutionalise these interpretations as laws. In accordance with pragmatist commitments to radical pluralism and democratic participation, the conflictual theory of law offers a basis for including all those potentially affected by a law within continuous processes of law production, challenge

1 Irregular migration is defined as 'the movement of people across borders without the explicit sanction of the receiving state' (McNevin 2017, 255). Hence, irregular migrants include refugees, asylum seekers and, so-called, "economic migrants". Moreover, the term irregular migration accounts for the fluidity of migration statuses and the contestation of distinctions between different attempts to categorize migrants (McNevin 2011, 19). 
and amendment. This inclusive theorisation of the law-making accords significance to the rights- and recognition claims of diverse and fluid groups and challenges static conceptions of citizenship in favour of an open-ended participatory processes. Thus, according to the conflictual theory of law, laws emerge as temporary solutions to social problems, which are themselves intersubjectively constructed by socio-political actors. These laws remain contested and are justified by their problem solving ability for all those affected by the laws in question. Each justification is contextually situated and dynamic, in line with underlying societal change.

The remainder of this article is organised as follows: The first section sets out the pragmatist philosophical basis of the conflictual theory of law, including its underlying theory of truth and implications for democracy and creative action. The second section evaluates competing social theorisations of laws both for their correspondence with the philosophical commitments set out in the first section and for their democratic implications. The third section builds on a social conception of laws to advance the conflictual theory of law, rooted in a combination of pragmatism and the Sociology of Knowledge Approach to Discourse (SKAD). ${ }^{2}$ The conflictual theory of law recognises the material implications of intersubjective meaning creation between socio-political actors, particularly through the institutionalisation of knowledge constructs and discursive formations as law.

\section{American Pragmatism as a Justification for Democracy and Law}

American Pragmatism's significance for the conflictual theory of law is evident in in its conception of truth as well as its implications for democratic politics and law-making processes therein. Pragmatism has its origins in the ideas of the founders of the Metaphysical Club in 1872, namely Peirce, James and the future United States Supreme Court Justice Holmes. Pragmatists question the existence of 'basic or incorrigible truths', despite affirming the foundation of knowledge in tacitly held beliefs about the universe (Peirce 1974, 394-397; Bernstein 2010b, 34-36). Their commitments to fallibilism and empirical scientific inquiry result in processes taking on a central role in the assessment of

2 SKAD is a framework for discourse analysis, which stresses the importance of reconstruction through both empirical research and interpretive theorisation (Keller 2017, 62, 65). This approach pushes back against readings of Foucault that reject interpretation (as a quest for true meanings) and opposes academic relativism (Keller 2005, 11). Thus, Keller seeks to 'translate some Foucauldian insights on discourse into sociological theory building' based on a social constructivist tradition that accords greater significance to actors and practices $(2005,2)$. 
truth claims. While there is some disagreement between Peirce and James about the nature of truth, pragmatists share a belief in the idea that truth(s) can be arrived at through argument, experience and the convergence of reasoned opinion over time (Hookway 2002, 2013).

Despite rejecting epistemic universals, and, hence, refusing to accept current truths as absolute, pragmatism is not relativist (James 1907, 106). Rather, by rejecting Cartesian dualisms James suggests that a researcher must neither uphold fictions of 'ultimate fixed foundations' nor descend into 'foundationless relativism' (Bernstein 2010b, 54). By recognising humans as 'in certain practical respects, creators of knowledge and truth' Peirce and James are able to dismiss the relativist 'fantasy of global doubt', recognising instead the inherent conservatism of ones pre-existing beliefs and the practical consequences of such beliefs and their amendment (Malachowski 2013, 40-41, 44-45). Taken together these commitments suggest that, rather than abandoning evidentiary standards for practical efficacy, new beliefs must fit into existing working systems of belief and behavior unless the new beliefs, 'when distributed throughout the human-world continuum, make the whole set up function in tangibly better ways, or do not damage it appreciably' (Malachowski 2013, 45-46). This processual approach to truth accords with human inability to achieve a 'God's Eye view' (Putnam 1981) and the ensuing need for 'critical engagement with other points of view and with other visions' (Bernstein 2010b, 62).

The conception of truth around pluralistic inquiry helps the researcher challenge allegedly fixed and universal legal "truths" in favour of the constant (re)negotiation of laws between social actors. This need for engaged inquiry is compatible with Peirce's assertion that the community of inquirers is never fixed (Peirce 1974, 221) and James' assertion that a belief in pluralism also triggers an ethical commitment to assuming that groups do not have static identities (Bernstein 2010b, 69). These epistemic commitments have implications for determining who should take part in social problem and solutions definition processes, including through democratic politics and legislative amendments. Thus, as elaborated in the next section, the pragmatist epistemology of discovering truth through prolonged pluralistic inquiry becomes the basis for evaluating legislative validity claims.

The significance of pragmatist conceptions of truth and pluralistic inquiry for democracy and law are explicit in the scholarship of Dewey, who views democracy as a form of government that goes beyond the electoral arithmetic of majority, focusing instead on 'the process by which the majority is formed' as well as ways in which the 'minority are represented in the policy which they force the majority to accept in order to be a majority' (1888, 8-10). Dewey's early writings should not be misunderstood as a denial of social conflict or the 
imposition of a unified will (Westbrook 1991, 40). Rather, different competing interests and conflicts are necessary drivers for both justice and social reform, since they provide the basis of deliberation and for the definition of social problems and solutions. As such, the knowledge underlying decision making in Dewey's highly participative version of radical democracy is attained through the active involvement of all members of society in democratic processes. Hildebrandt argues that Dewey's pragmatism has a 'melioristic motive', which views life as improvable 'primarily through intelligent, human effort' (Hildebrandt 2013, 59). Such creative conflict requires a pluralistic culture that allows for and encourages differences of opinion and debate to resolve social problems (Bernstein 2010b, 80, 85, 86; 2010a, 302). Within the continuously improvable practice of democracy 'deliberation of all those affected by a decision would be superior to any other possible method of inquiry' (Bohman 2010, 189, 199).

Thus, a case can be made for including irregular migrants, members of their host communities and civil society groups engaging with migrants in the political deliberation and law-making processes that effect their condition within this (new) community. Further, while democratic progress can be achieved by improving deliberative inquiry in cooperative practices, 'normative practical inquiry must seek to extend the scope of political possibilities rather than simply accept the facts and the institutions that produce and stabilize them as fixing the limits of political possibilities once and for all' (Bohman 2010, 200201). Members of society are called to consciously reflect on social reality and the changes occurring therein in order to creatively adjust their institutions in response to the critical evaluation and deliberation of social facts. As such, Dewey emphasises that ' $[\mathrm{d}] \mathrm{emocracy}$ as a way of life' requires 'faith in the potentialities of human nature as that nature is exhibited in every human being irrespective of race, color, sex, birth and family, of material or cultural wealth' and a belief in human equality $(1988,2)$.

Beyond Dewey's pragmatist account of democracy, Silva argues that Mead offers scholars a communicative social theory 'that systematically connects science's problem-solving nature to democracy's deliberative character by means of social psychology that establishes the social nature of the human self' (2007b, 291-293). The intersubjective construction and reconstruction of social realty by 'taking the role of the other' becomes the mind-set of social psychologists, researchers in the sciences and participants in democratic politics (Silva 2007b, 291, 296). Thus, social progress is about harnessing sympathy, by assuming the role of the other, and science, as experimental innovation based on the scientific method (Mead 1910 in Rigney and Lundy 2015, 167-168).

Mead's theory of action highlights the 'tension between the creativity of action and the communicative character of human sociability' (Joas 1990, 167). 
Ends are not set 'outside the context of action' and instead emerge as 'the result of reflection on resistances encountered by the variously oriented behavior' of participants in a social context. This interpretation applies to how parliamentarians advance and deliberate new laws, particularly in light of the resistance encountered within parties or coalitions, from courts and other external stakeholders as well as from discourses and narratives put forward by other parliamentarians. Extrapolating these principles to the social level, Mead believed that social order was not achieved through normative consensus but instead through the capacity of a collective to successfully resolve social problems (Joas 1990, 185-186). This approach should not be misunderstood as a positivistic faith in the permanent resolution of political and moral problems using scientific methods. Rather, the scientific approach should be viewed as a fruitful method for resolving specific cognitive challenges, not postulating universal maxims (Joas 1990, 188).

\section{A Deeply Social Conception of Laws}

As an antifoundational philosophy, theorists have interpreted pragmatism in divergent, sometimes contradictory ways. In theorising the nature of laws, some interpretations attempt to strip pragmatism of its normative implications, thus severing the link between pragmatism's epistemology and the implications thereof for validity claims. These theorisations suggest that pragmatism views law as nothing more than context specific experimentation, offering no guidance as to what types of laws or legislative processes are socially desirable. One such challenge for linking pragmatism, radical democracy and their implications for a social conception of laws is posed by Rorty, who alleges that ' $[\mathrm{t}]$ he bridge $[\ldots]$ between epistemic and political democracy is too flimsy to carry heavy traffic' (Posner 2003, 113 in Rorty 2007, 918). Rorty suggests that 'by now pragmatism is banal in its application to law', as judicial practice has generally recognised the value of experience over universal logics (1990, 1811). In this reading of pragmatism both democracy and law are left entirely without moral or political direction.

A rebuttal of Rorty's interpretation might begin by highlighting pragmatism's essential anti-dualism and, hence, the refusal to draw firm distinctions between ends and means. Faber recognises that Dewey strongly opposed instrumentalism, suggesting instead that means were 'themselves part of the consequences of a decision' $(1988,1345)$. It emerges unmistakably from Mead's systematic linkage of scientific inquiry, deliberative democracy and social psychology through 'taking on the role of the other' that pragmatism can offer an inclusive, pluralistic method for resolving social problems, whether these 
pertain to law, democratic politics or other matters. Mead and Rorty would agree that the constant reconstitution of society does not follow a-priori, universalist maxims. Thus, Rorty defends epistemic antifoundationalism by highlighting the importance of defending legal premises based on their practical consequences, not reference to a higher authority (1992, 719, 720).

While agreeing with this sentiment, Mead goes beyond Rorty in suggesting that pragmatist inquirers are guided in their proposals by procedural commitments to scientific rigour, pluralistic inquiry and engagement with the 'generalised other' in order to achieve moral progress, which can manifest in better, more just laws for all members of society (Silva 2013, 463). As recognised by Silva, Mead's communicative theory of society connects democracy, law and ethics by envisioning an ideal political community where social order is based on rational arguments, mutual understanding and, hence, constant 'intelligent social reconstruction' in response to social change $(2007 \mathrm{~b}, 298,301)$. This intelligent social reconstruction, and moral reconstruction in particular, is guided by a proceeduralist belief in a 'democratic and experimental moral method' (Silva 2007b, 303). In accordance with the pragmatist method, laws can be interpreted as demarcations of temporary compromise within an ongoing trajectory of social reconstitution and reform. When merged with commitments to radical pluralism and open-ended inquiry, the processes underlying legal change can be conceived of as either converging on pluralistic and inclusive ideals (for example by opening legal deliberation to affected but previously disenfranchised members of the society) or moving away from the same (for example by actively excluding directly affected members of the society from legislative deliberations). Thus, rejecting epistemic universals does not entail moral relativism. Rather, validity claims can be evaluated based on their ability to inclusively address situated social problems. Pluralistic and inclusive practices create ideal conditions for the emergence of creativity and hence the continuous reconstruction of existing legal frameworks in ways that better meet the needs of society as a whole.

Contra Rorty, Misak uses Peirce's commitment to true beliefs, as those that are sustainable across as many diverse experiences as possible and over time, to argue that laws can be evaluated both based on the procedures by which they were devised and by assessing whether the reasons for a law stand up to prolonged pluralistic inquiry $(2017,285,296,304)$. Similarly, Joas suggests that Rorty systematically ignored the 'truly radical element' of both Dewey and Mead's critique of existing political institutions and their ability to realise the democratic ideals envisioned in classical pragmatism (1990, 190). As a result, Rorty's philosophical relativism misses the potential that Dewey and Mead accord to philosophy as a means of social reconstruction and reform (Joas 1990, 190); a process in which law plays an essential role in institutionalising each 
reconstruction of social reality and its rules. Dewey made this commitment explicit, when emphasising that 'philosophy is not a special road to something alien to ordinary beliefs, knowledge, action, enjoyment, and suffering. It is rather a criticism, a critical viewing, of just these familiar things. It differs from other criticism only in trying to carry it further and to pursue it methodically' $(1930,23)$. As such, creativity and criticism including of existing legal and democratic institutions 'cannot be separated', criticism being the 'friend and ally' of creative production and social reform (Dewey 1930, 12, 21).

In line with the rebuttal of Rorty's reluctant neopragmatic approach, Silva postulates a neo-Meadian alternative to 'liberal political theory' and its natural law inspired, individualistic, material and universal justification for rights, accorded a-priori to individuals as a result of their sheer humanity. He contends that rights are the product of social processes of imagination, contest, implementation and denial, which have the effect of 'constituting action' $(2013,458)$. By defining rights as mutual relations consisting of political claims that have the ability to constitute 'individuals into citizens' and to constrain human action, Silva recognises the contingency and situated nature of rights claims and their perpetual vulnerability to social attitudes and political processes. This contingency is particularly apparent with respect to those members of society, who are neither accorded the political rights of citizenship nor access to the comprehensive human rights protection imagined by liberal theorists and inscribed in international treaties such as the UDHR and the European Convention on Human Rights (ECHR).

As alluded to throughout this article, irregular migrants constitute a compatibility problem between universal formulations of human rights and the question of access to those rights through what Arendt terms the 'right to have rights' within a nation state $(1973,296)$. Specifically, '[f] or Arendt, the problem for the stateless was political membership,- - that without citizenship, refugees had no state to uphold their rights' and, hence, the 'right to have rights' includes a claim for membership in the political community of a refugee's host state and a right to political participation therein (Hirsch and Bell 2017, 422, 425). Arendt recognises this incompatibility as a major challenge to liberalism, which is ostensibly committed to both 'an unwavering respect for human rights' and to state sovereignty, including a state's control over its borders (Lamey 2011, 235). The conflictual theory of law advanced at the end of this article addresses the demands of irregular migrants within a given nation state, as a particularly vulnerable segment of society and makes the case for recognising and incorporating them into the negotiations that define the breadth and depth of human rights protections accorded by that state.

In light of Silva's recognition that rights are the product of historically contingent social processes (2013), it is these negotiations of rights and their 
institutionalisation as laws that must be the focus of a deeply social conception of rights, not the abstract and ahistorical prescriptions of natural law. As alluded to throughout this article, American Pragmatism, particularly in the iterations of Mead and Dewey provides insights into how such processes should ideally be conducted. In accordance with the commitment to pluralistic inquiry using a large, diverse and open-ended group of inquirers, legislative processes should constitute a critical engagement with existing, contextually situated legal frameworks in order to assess whether these institutions reflect the social circumstances, experiences and social problem constructions therein. This processual lens allows the researcher to question the rigid dichotomy between citizenship- and human rights (Silva 2013, 459), which is drawn by most national constitutions, including, for example, the German Basic Law. ${ }^{3}$ By seeking to broaden the groups of participants in processes that enact or amend legislation to all members of society that are affected by a policy, whether they are citizens or not, the potential for creative social reform is harnessed. This conclusion harmonises with Mead's internationalist instincts and his recognition that political conversation in strictly nationalist terms falls short of the ideal of the 'generalised other' (Silva 2007b, 300).

From this perspective, it seems natural to recognise and include irregular migrants within a state's political community and, hence, its contemplation of the 'generalised other'. This form of political membership is justified both by irregular migrants' presence within a state's territory and by the direct effect that the regulation of migration and asylum has on them. Pluralist inclusion can be achieved by other socio-political actors entering communicative relationships with irregular migrants, which entails recognising and contemplating their predicaments and demands within the legislative process, as an intersubjective arena of rights contestation. It is important to emphasise that the context-dependent and communicative setting of ends does not depend on all socio-political actors achieving either normative consensus or a homogeneous outlook for the creative resolution of social problems to succeed. Rather, 'the solution of moral problems requires creative intellectual accomplishments and the taking into account of all the values that are relevant in the situation in question' (Joas 1990, 182). As such, the normative implications of Mead's

3 The Basic Law accords specific rights of democratic participation, such as the freedom of assembly (Article 8, Basic Law), the right to form societies and associations (Article 9, Basic Law) and the freedom of movement within Germany (Article 11, Basic Law) specifically to citizens. 
'communicative type of rationality' emerge from its procedural commitments: 'The solution of moral problems lies in being able to have the widest perspective possible so that all the conflicting points of view, interests, or ends are fully appreciated' (Silva 2007b, 303).

Since 'there is no unequivocal criterion for the success of problem solving other than that of those concerned with and affected by the problem' (Joas $1990,185,186)$, the preconditions for the creative resolution of social problems through law lies in critical reflection on existing legal and institutional frameworks and their consequences. When approaching a social problem defined around a moral issue, Mead suggests that this 'problematic situation' can be reconstructed either by deductively reaffirming old meanings in relation to the problem or inductively searching for new meanings, the latter being 'superior since it treats moral problems as occasions for moral growth' (Silva 2007a, 56). For example, when confronted with increasing irregular migration, political decision makers have the opportunity to rethink existing legal frameworks for regulating migration, which often fail to explicitly account for several of the principal causes of irregular migration including extreme poverty and environmental catastrophes. Thus, a pragmatist 'ethics does not elucidate the validity of the ultimate values, but instead attempts to reconstruct empirically the procedure for resolving situations requiring moral decisions in such a way that in it a procedure becomes recognizable that can itself serve as a basis for its own self-perfecting' (Joas 1990, 183). Specifically, the Meadian ideal of creativity recognises that ' $[\mathrm{h}]$ uman action is neither the realization of norms nor the fulfillment of drives: the individual is engaged in a continuous process of drawing boundaries and of opening them vis-a-vis other individuals and the collectives with which he is associated' (Joas 1990, 185).

A final characteristic of rights claims that lies at the heart of the process by which solutions to social problems are conceived and deliberated is their fictive, imagined character (Silva 2013, 468-469). Until rights are made "material" through their institutionalisation as binding laws, and the conferral of symbolic significance onto them through codification in statutory form, they remain subject to the imagination, reimagination and denial of members of the political community. For example, the rigid distinctions drawn by countries between different groups of irregular migrants and their elevation of protected refugees over other categories of unprotected irregular migrants is the consequence of a particular human rights imagination codified in response to specific historical legacies, including the aftermath of the Second World War. As such, the creative agency of socio-political actors in the 'collective socio-legal practice of world-making' around rights claims is made explicit (Silva 2013, 
469). Consequently, rights claims can be characterised as 'as powerful symbolic political resources, from which concrete experiences of indignation can draw so as to criticize and transcend the existing social and political order' (Silva 2013, 466).

\section{The Conflictual Theory of Law}

The conflictual theory of law builds on the deeply social conception of laws defended in the previous section and the SKAD framework to analyse the processes by which laws, as social institutions, are negotiated and institutionalised. Hence, the conflictual theory of law is neither a genealogy of rights nor a school of jurisprudence. It is also distinguishable from legal pluralism, which regards the state as only one of many sources of law. Rather, the conflictual theory of law is concerned with how democratic societies deliberate laws through the parliamentary process. Despite its focus on the national legislative realm, the conflictual theory of law is attuned to the significance of other political arenas, both at the supranational level and the intranational level.

The conflictual theory of law is structured around a reimagination of Hilgartner and Bosk's public arenas model for assessing the 'careers of social problems' $(1988,53,56)$. Originating in Blumer's symbolic interactionist conception of social problems, the model was designed as an arena-centric attempt to study the evolution of social problem definitions in light of competition from other social problems. The conflictual theory of law evaluates the trajectories of social problems and, more importantly, the careers of solutions thereto within the realm of legislative deliberation. In reinventing the public arenas model, the conflictual theory of law engages with both the pragmatist aspirations for legislative deliberation, emergent from the deeply social conception of laws and the analytical devices of the politics of knowledge (and its social construction), as identified by SKAD. These devices include subject positioning, practices, dispositifs and principles of symbolic ordering (Keller 2012). As such, the six pillars of the conflictual theory of law reveal different aspects of the processes by which social problems emerge and attain prominence as well as the processes by which their solutions are conceived, affirmed and institutionalised as laws:

1. Competition among a large set of social problem and solution claims within the legislative process;

2. institutional arenas in which social problems and their proposed solutions compete for attention and which confer epistemic privilege on 
actors, thus influencing the definition of social problems and possible legislative solutions thereto;

3. arena 'carrying capacities', which limit the number of problems and proposed solutions that can gain attention and legislative priority at any one time;

4. 'principles of selection' or institutional, political, and cultural factors, influencing the probability that competing problem and solution formulations succeed within the legislative process;

5. patterns of arena interaction, which allow activities in one arena to spread to other arenas, for example through the interaction of media and politics; and

6. actors and their networks, which promote and seek to control individual social problems and solutions and their definitions across several arenas.

As pillars of the conflictual theory of law, these six elements allow researchers to break down the socio-political processes underlying law-making and legislative amendment into their constituent elements and to analyse each element in turn. As hinted at above, each element is evaluated in light of its relationship with the deeply social conception of laws as creative solutions to social problems arrived at by means of open-ended, inclusive and pluralistic inquiry among all those affected by the law in question. As such, the conflictual theory of law aligns with Putnam's philosophical justification of democracy as the 'the precondition for the full application of intelligence to the solution of social problems' and his commitment, not to a 'universal theory of everything' but to allowing the 'best available knowledge of its own time and place' to guide the resolution of social problems $(2017,251,255)$. It also submits, contrary to classical liberalism, that the elimination of constraints does not itself lead to the emergence of rights (Putnam 2017, 262-263). Rather, the origins of rights claims lie in the identification of social problem experiences and, hence, rights as proposed ameliorations of social problem experiences have to be achieved and defended in light of other conceptions of social order (Pappas 2017, 85). As such, the rights claims of irregular migrants often challenge pre-existing selfconceptions of nation states, both in terms of sovereignty and national identity (Hirsch and Bell 2017, 422). The remainder of this section expands upon the six pillars of the conflictual theory of law, commencing with competition among social problem claims.

The first pillar of the conflictual theory of law highlights the broad spectrum of possible social problems and solutions each representing 'a specific interpretation of reality from a plurality of possibilities' (Hilgartner and Bosk 1988, $57-58)$. Both problems and solutions are highly 'stratified' in accordance with 
their 'celebrity' within legislative arenas and with the capabilities and prominence of proponents of particular problem and solution conceptions therein. Equally, the longevity, disappearance or (re)emergence of each problem conception and solution proposal within 'public consciousness' is extremely variable and subject to a 'highly selective process in which they compete with one another for public attention and societal resources' (Hilgartner and Bosk 1988, 57). Thus, the prospects of different social problem definitions as well as their purported solutions depend on the process of their collective definition within arenas, in which success results from competitions for attention. Within these arenas the competitive process between different social problems and solutions occurs at two levels: First, different 'substantive areas', in which problems and their solutions can be defined, compete for the attention of publics, the media and politics. Second, within each 'substantive area', such as a state's response to increases in irregular migration, different definitions of the social problem attempt to (re)frame it in ways which implicitly or explicitly prefer one or another means of solving the problem (Hilgartner and Bosk 1988, 70). By accounting for the careers of solutions within the legislative realm, the conflictual theory of law goes beyond the public arenas model in explicitly recognising the lasting material impacts of definition and institutionalisation processes.

In contemplating social solutions, the conflictual theory of law incorporates Honneth's insight of the pivotal significance of recognition, particularly within the legislative realm (2004). From this perspective, 'distribution conflicts' and 'recognition conflicts' are never entirely distinct (Honneth 2004, 353), which implies, for example, that social problems defined around irregular migration and alleged "capacities" to accept asylum seekers are, in fact, claims about the recognition perceived by different groups within society. The conflictual theory of law submits that the importance of recognition claims and the resolution of 'recognition conflicts' within the legislative realm is best achieved using an inclusive deliberation process, which considers the articulation and reception of recognition claims as intrinsically valuable. Thus, as Honneth recognises, progress can be achieved in one of two ways: 'either new personality portions are disclosed to mutual recognition, so that the degree of socially confirmed individuality increases, or a greater number of persons is included in the already existing recognition conditions, so that the circle of mutually recognizing subjects grows' (2004, 361).

The definition of 'social problems occurs not in some vague location such as society or public opinion. Rather, they arise in public arenas where social problems are framed and grow' (Hilgartner and Bosk 1988, 58) and which range from parliaments to news media platforms, civil society, to courts and 
regulatory bodies. As a theory concerned with the negotiation of social problems and their solutions in the national legislative realm, the principal arena for the conflictual theory of law are national parliaments (including their various specialist committees). In addition to the principal law-making organs of the federal government, the news media constitutes an important arena of legislative deliberation since for 'most members of the civil sphere, and even for members of its institutional elites' the news media constitutes the 'only source of firsthand experience they will ever have about the vast majority of their follow citizens, about their motives for acting the way they do, the kinds of relationships they form, and the nature of the institutions they create' (Alexander 2016, 1).

Similarly, supranational institutions such as the European Union (EU) and intranational decision making bodies in devolved systems of government or federal states contain parallel arenas to the national level, in which social problems and their solutions are negotiated in ways that prompt synergies and frictions with the national level. The institutional infrastructure of the Eu creates a range of supranational arenas, including the European Commission, the European Council, the European Parliament, the European Court of Justice (ECJ) and the European Court of Human Rights (ECtHR) as well as hundreds of specialist arenas. Unlike decisions made by other international bodies, the legally binding and directly effective nature of many EU decisions allows these arenas to shape and curtail the definition of social problems and their solutions at the national level. For example, the ECtHR's 2012 decision in Hirsi Jamaa and Others $v$ Italy [GC], (Application No. 27765/og) set out binding criteria for achieving 'individual, fair and effective' refugee status determinations in the EU member states. At the same time, national governments are able to exercise considerable leverage over the problems and solutions derived in several EU arenas.

As such, the institutional arenas introduced in this subsection allow the conflictual theory of law to account for the contexts in which actors formulate means of symbolic ordering such as 'horizons of expectations', 'specific visions' and 'speaker positions' to dominate the definition of social problems and their solutions (Cantoni, Klaes, et al. 2018, 535, 538). Specifically, each arena's institutional structures and logics of knowledge construction accord and distribute epistemic privilege on actors in accordance with their positions within hierarchies (based on rank or importance within an institution) or the resonance of their narratives with an arena's intrinsic logics (for example "news-worthiness" in the media realm or "decisiveness" in parliamentary debates). The extent to which these structural factors exclude or silence individuals affected by the social problems and solutions negotiated within an arena, provide the pragmatist 
researcher with grounds for criticising existing legal orders and, thus, constitute areas for potential moral growth.

As alluded to in the previous subsection, each institutional arena exhibits a maximum number of social problems and potential solutions per social problem that can be sustained at any one moment. Capacity can manifest in concrete terms through metrics such as the number of minutes accorded to a particular topic in a session of parliament, the number of columns accorded to a story in a newspaper or the airtime accorded to an issue on television but is also sensitive to less quantifiable metrics such as 'surplus compassion' (Hilgartner and Bosk 1988, 59) and creativity, particularly for devising new solutions to social problems. Thus, the number of social problems ascertainable in an arena at any point in time does not typically reflect the number of material challenges encountered within that society, but the carrying capacity of the arena. Similarly, the emergence and career of a proposed solution to a social problem articulated in a given arena depends on the time and resources allocated to other solution proposals and, hence, the remaining capacity of the arena for novel solutions.

Thus, unless the carrying capacity of an arena is expanded, the increase in prominence of one social problem definition or solution proposal, will reduce the pervasiveness of its alternatives. As recognised by Keller, 'the conflicts, issues, commitments, and resources available for the definition of collective situations-including things, actors, animals, objects, values, ways of doing, justifications, and so on-never cease' $(2017,64)$. While some actors and researchers may be in the business of '[p]retending that reality is the way it is and must be the way it is' social change has transformative effects on the character and operating principles of institutional arenas, including through the introduction of new sub-arenas. Shifts in arena capacity and composition notwithstanding, the conflictual theory of law suggests that political strategies can capture an arena both by absorbing its existing carrying capacity and undermining other claims to the arena in question.

In light of this theorisation of institutional arenas and their carrying capacities, the conflictual theory of law is able to frame the space in which actors engage with each other in relation to various subject areas. This acute awareness of the attributes of each arena facilitates the use of SKAD to analyse "[s] ocial relationships of knowledge' as the 'complex sociohistorical constellations of production, stabilization, structuration and transformation of knowledge within a variety of social arenas' (Keller 2012, 59). As such, the 'specific visions' produced by actors to further their objectives are based on 'established or emerging speaker positions', which themselves derive from their institutional arenas and the constraints thereof. Thus, the combination of different institutional arenas 
and their limitations paves the way for the theorisation of the tools, logics and strategies, which tend to prevail in the national legislative realm.

The principles by which a problem definition is adopted or a proposed solution is implemented by actors in a given arena are a direct consequence of limited arena capacities and conflicting definitions of social problems and solutions therein. Hilgartner and Bosk recognise that selection criteria, such as 'the intense competition for prime space; the need for drama and novelty; the danger of saturation; the rhythm of organizational life; cultural preoccupations; and political biases', play out differently in each arena, arena importance and carrying capacity being significant determinants of intra-arena competition $(1988,61)$. Timing and the operational sequencing of each arena, for example by the news cycle or the segmentation of a parliamentary session, can also influence the effectiveness of a problem definition or a proposed solution (Hilgartner and Bosk 1988, 62-63). The conflictual theory of law recognises, contra Hilgartner and Bosk, that even when arenas appear saturated with particular tropes and symbols, the combination of fear and appeals to cultural and political biases can suspend the need for novelty, particularly in legislative arenas that are driven by the logic of "decisiveness".

As alluded to when setting out the institutional arenas of competition, the principles of selection operating within the arenas at the heart of the conflictual theory of law are influenced by 'asymmetric relationships of power', which underlie '[s]ocial relationships of knowledge', including the conferral of epistemic privilege on actors either because of their institutional rank or because of the resonance of their narratives within arena specific logics (Keller 2017, 62). Rather than identifying any one type of social problem definition or solution proposal as automatically dominant across different arenas as well as multiple temporal and spacial contexts, Keller recognises that struggles over the 'definition of the situation' are 'conceived as crystallized effects of complex constellations and historical becoming that cannot be explained using a onetheory-fits-all rationale' $(2017,62,64)$. Thus, the principles of selection in each historically and geographically contingent arena are attuned to the emergence, affirmation and amendment of power-laden subject positions, practices and dispositifs in the national legislative realm, as well as to the influence of other arenas on these processes. Phenomenological and narrative structures influence the careers of problem definitions and solution proposals by determining the themes and dimensions of possible social problems as well as their definitional characteristics, causal relationships, actor identities, normative judgements, consequences and action possibilities (Keller 2012, 68, 70). As such, discourse is used, for example, to cast actors as 'heroes, rescuers, problem cases, sensibly, responsibly acting individuals, villains, and so on' (Keller 2012, 68). 
The different arenas in which social problems and their solutions are negotiated are interdependent and, hence, '[f] eedback among the different arenas is a central characteristic of the process through which social problems are developed' (Hilgartner and Bosk 1988, 67). Feedback loops are the result of complex networks of interaction between the various arenas: Picture a parliamentarian making a controversial statement about migrants on a primetime television program in order to influence subsequent parliamentary debates about proposed amendments to a Germany's asylum law. These parliamentary debates will almost certainly be addressed and interpreted in later news broadcasts and publications. Such interconnected arenas have the potential to produce synergies that can facilitate the dominance of a particular social problem or proposed solution in multiple arenas. Conversely, social problem definitions and proposed solutions may experience crowding out effects across different arenas, for example when a particular salient problem definition or solution proposal absorbs the carrying capacities of more than one arena, thereby starving off alternatives. Equally, one arena's principles of selection may affect arenas that would otherwise have applied different selection criteria. For example, parliamentarians might feel pressured to address polarising media discourses around "dangerous", unregistered migrants in parliamentary debates to avoid being viewed as irresponsive to the concerns of "the public". Similarly, arenas at the national level are almost never independent from social problem definitions and proposed solutions at the intranational and supranational levels.

As such, actors in the German Bundestag might be enabled by claiming that a legislative solution would strengthen legal harmonisation across the EU or would pave the way towards common European standards. This tactic was employed by German parliamentarians of the conservative political spectrum in the early 199os to argue that German asylum law was too generous and that such generosity inhibited EU-level cooperation on asylum related matters. Conversely, the failure of heads of state in the European Council to agree on binding quotas and a functioning distribution mechanism for irregular migrants during the so called "refugee crisis" of 2015/16 put significant pressure on the governing coalition in the Bundestag to devise a national response to social problems constructed around the arrival of irregular migrants. At the same time, the scope for national solutions was constrained by Eu level rules, such as the Schengen Agreement's commitment to open borders within the EU and prescriptions regarding which country is formally responsible for a given irregular migrant.

In light of these intranational, national and supranational arenas and their complex patterns of interaction, the conflictual theory of law recognises that 
'even if the tangled webs of social life powerfully influence our experiences and do much to shape our behaviour, identities and interests' it is ultimately the individual actors within each arena that engage in creative action, thereby actively reconstituting social reality (Konings 2010, 59). Thus, arenas and the institutions that underpin them are never just negative constraints on individual action (Konings 2010, 70), as experiences of institutions, resistances encountered therein and institutional discrepancies with reality underpin creative action.

Given pragmatism's recognition of actors' agency in creatively reconstructing their social reality, the theorisation of actors and actor networks is a central component of the conflictual theory of law. '[A]ctors do not so much perform positions in a structure but rather pragmatically use the grid of institutional markers available to them: they rely on and employ publicly available norms and rules to improve their conceptual and practical grip on the world, in the process constructing their identities as social actors' (Berger and Luckmann 1966, 61 in Konings 2010, 66-67). The institutionalisation of any one rule or norm places the operation of social power relations both within and across arenas on a structural footing, thereby privileging the agency of some actors over others. When confronted with social change and associated challenges to the distribution of capacities and resources within existing arenas and their institutions, these challenges trigger questions about the adequacy of existing arrangements and the potential for creative innovation and social reconstruction (Konings 2010, 71-72).

The conflictual theory of law recognises that, while actors and actor networks can and do establish privileged positions for themselves, these positions remain contested as social problems and solutions are perpetually (re)defined, with each proposed definition implying different specialist actors and networks. As such, the increase in irregular migrants arriving in a country can be viewed, amongst other things, as predominantly an issue of labour market integration (experts including corporate executives and industry associations), border management and terrorism prevention (with experts in the police and the interior ministry), cultural preservation (experts being representatives of the "true people") or human solidarity (with expertise conferred on volunteering organisations and civil society groups).

In line with these insights on the agency of actors and actor networks, the conflictual theory of law incorporates the SKAD framework's theorisation of subject positions. Keller identifies that subject positions manifest in two ways: as the holders of 'speaker positions' and as 'statement producers' with varying levels of epistemic privilege and, second, as the 'addressees of the statement practice' $(2012,62)$. As anticipated by Berger and Luckmann 
and the public arenas model, these subject positions manifest sociologically in the form of 'institutions, organizations, roles, and strategies of the individual or the collective'. However, subject positions are also discernible within discourse as 'positioning processes' and 'patterns of subjectivisation' (Keller 2012, 62). For instance, the characterisation of irregular migration as a "floodlike" phenomenon, through the use of phrases such as "Migrantenstrom" (migrant-stream, author's own translation), "Flüchtlingswelle" (refugee-wave, author's own translation) and "Flüchtlingsflut" (refugee-flood, author's own translation) in political and media arenas in Germany conceives of irregular migration as akin to a natural catastrophe. This depiction not only obscures the gravity and complexity of the causes of irregular migration and disindividuates irregular migrants, who become viewed part of one overwhelming "stream", it characterises irregular migration as inherently severe and problematic, thus requiring an urgent response. Irregular migrants, who are defined as externalities without individual or collective agency within Germany, are thus excluded from intersubjective social problem and solution negotiation processes.

To counteract this shortcoming of existing law-production processes across the world, the conflictual theory of law recognises citizenship as a fluid and dynamic concept. Fluidity and dynamism manifest in overlapping dualcitizenships, the advent of supranational EU-citizenship, shifts from recognising bloodline citizenship (ius-sanguinis) to birth-right citizenship (ius-soli) as well as the emergence of various forms of semi-citizenship or citizenshipfor-sale. As such, recognising fluidity and dynamism is both a recognition of changes in the reality of the practices and institutions of citizenship as well as an aspiration for how nation states should respond to the negotiation of social problems and their solutions in realms that affect individuals other than the formal citizens of that country, including in response to irregular migration. As reality is not stratified neatly into independent local, national and global layers, 'one cannot simply disaggregate the various types of rights of the modern conception of citizenship and redistribute them according to different levels of governance' (Silva and Brito 2009, 74). Consequently, political participation must be attuned to the empirical contexts in which the rights, actions and experiences commonly associated with citizenship manifest. Thus, in the spirit of pragmatism's commitment to openended pluralistic inquiry among the widest possible group of inquirers, all members of a society however temporary and irrespective of formal citizen status should be recognised as legitimate participants in the legislative deliberation of social problems and solution proposals that have a direct effect on them. 


\section{Conclusion}

This article contributes to the study of knowledge-creation within legislative deliberations by introducing the conflictual theory of law as a way of understanding laws as social struggles over meaning. The six pillars of the conflictual theory of law enable the researcher to break down the process of lawproduction into its constituent elements, identifying the significance of actors, practices and arenas of social problem definition, negotiation and resolution therein. In contrast to natural law foundationalism, the institutionalised solutions to rights and recognition claims are theorised as contextually situated, dynamic and contingent. The philosophical underpinnings of the conflictual theory of law in American Pragmatism allow the researcher to reject epistemic universals, while simultaneously pushing back against moral relativism. In fact, the pragmatist commitment to testing truth claims across as many different experiences and inquirers as possible, allows the researcher to evaluate laws and law-making processes by examining whether legislative solutions to social problems were derived by means that were inclusive, participatory and open-ended.

\section{Acknowledgments}

I would like to take this opportunity to express my sincere gratitude to the Cambridge Commonwealth, European \& International Trust; I gratefully acknowledge the Trust's support in publishing this article open-access. There is no conflict of interest.

\section{Works Cited}

Alexander, Jeffrey C. 2016. "Introduction: Journalism, democratic culture, and creative reconstruction," in The Crisis of Journalism Reconsidered, ed. Jeffrey C. Alexander, Elisabeth Butler Breese and Maria Luengo (Cambridge, UK: Cambridge University Press), pp. 1-28. https://doi.org/10.1017/CBO9781316050774.002.

Arendt, Hannah. 1973. The Origins of Totalitarianism. Boston: Houghton Mifflin Harcourt.

Bernstein, Richard J. 2010a. "Dewey's vision of radical democracy," in The Cambridge Companion to Dewey, ed. Molly Cochran (Cambridge, UK: Cambridge University Press), pp. 288-308. https://doi.org/10.1017/CCOL9780521874564.

Bernstein, Richard J. 2010b. The Pragmatic Turn. Oxford, UK: Polity Press. 
Bohman James. 2010. "Ethics as moral inquiry: Dewey and the moral psychology of social reform," in The Cambridge Companion to Dewey, ed. Molly Cochran (Cambridge, UK: Cambridge University Press), pp. 187-210. https://doi.org/10.1017/CCOL9780 521874564 .

Cantoni, Roberto, Klaes, Matthias S., Lackerbauer, Simone I., Foltyn, Claudia, and Keller Reiner. 2018. "Shale tales: Politics of knowledge and promises in Europe's shale gas discourses," The Extractive Industries and Society 5(4):535-546. https://doi .org/10.1016/j.exis.2018.09.004.

Da Silva, Filipe C. 2007a. "G.H. Mead: a system in a state of flux," History of the Human Sciences 20(1): 45-65. https://doi.org/10.1177/0952695107074671.

Da Silva, Filipe C. 2007b. "Re-examining Mead: G.H. Mead on the 'Material Reproduction of Society', Journal of Classical Sociology 7(3): 291-313. https://doi.org/10.1177/ 1468795 X07082083.

Da Silva, Filipe C. 2013. "Outline of a social theory of rights: A neo-pragmatist approach," European Journal of Social Theory 16(4): 457-475. https://doi.org/10.1177/ 1368431013484001.

Da Silva, Filipe C., and Brito, Monica V. 20og. "Plural Modernity: Changing Modern Institutional Forms-Disciplines and Nation-States," Social Analysis 53(2): 60-79. https://doi.org/10.3167/sa.2009.530204.

Dewey, John. 1888. "The Ethics of Democracy," rep. in University of Michigan Philosophical Papers 1. Second Series (Michigan: Andrews), pp. 1-28.

Dewey, John. 1930. Construction and Criticism. New York: Columbia University Press.

Farber, Daniel A. 1988. "Legal Pragmatism and the Constitution," Minnesota Law Review 72: 1331-1378.

Fraenkel, Ernst. 2011. Deutschland und die westlichen Demokratien. Baden-Baden, Germany: UTB.

Hall, Stuart. 2013. "The Work of Representation," in Representation: Cultural Representations and Signifying Practices, ed. Stuart Hall, Jessica Evans, and Sean Nixon (Milton Keynes, UK: SAGE), pp. 13-74.

Hildebrand, David. 2013. "Dewey's pragmatism: instrumentalism and meliorism," in The Cambridge Companion to Pragmatism, ed. Alan Malachowski (Cambridge, UK: Cambridge University Press), pp. 55-8o. https://doi.org/10.1017/CCO9781139022132 .006 .

Hilgartner, Stephen, and Bosk, Charles L. 1988. "The Rise and Fall of Social Problems: A Public Arenas Model," American Journal of Sociology 94(1): 53-78. https://doi .org/10.1086/228951.

Hirsch, Asher L., and Bell, Nathan. 2017. "The Right to Have Rights as a Right to Enter: Addressing a Lacuna in the International Refugee Protection Regime," Human Rights Review 18(4): 417-437. https://doi.org/10.1007/s12142-017-0472-4. 
Honneth, Axel. 1998. "Democracy as Reflexive Cooperation: John Dewey and the Theory of Democracy Today," Political Theory 26(6): 763-783. https://doi.org/10.1177/ 0090591798026006001.

Honneth, Axel. 2004. "Recognition and Justice: Outline of a Plural Theory of Justice," Acta Sociologica 47(4): 351-364. https://doi.org/10.1177/ooo1699304048668.

Hookway, Christopher. 2002. Truth, Rationality, and Pragmatism: Themes from Peirce. Oxford, UK: Oxford University Press.

Hookway, Christopher. 2013. "Pragmatism," in The Stanford Encyclopedia of Philosophy, ed. Edward N. Zalta. At https://plato.stanford.edu/archives/sum2016/entries/ pragmatism/, accessed 10 June 2019.

Hopgood, Stephen. 2013. The Endtimes of Human Rights. Ihtica, New York: Cornell University Press.

James, William. 1907. Pragmatism: A New Name for Some Old Ways of Thinking: Popular Lectures on Philosophy. London, UK: Longmans, Green and Co.

Joas, Hans. 1990. "The Creativity of Action and the Intersubjectivity of Reason: Mead's Pragmatism and Social Theory," Transactions of the Charles S. Peirce Society 26(2): 165-194.

Keller, Reiner. 2005. "Analysing Discourse. An Approach From the Sociology of Knowledge," Forum Qualitative Sozialforschung 6(3). https://doi.org/10.17169/fqs-6.3.19.

Keller, Reiner. 2012. "Entering discourses: a new agenda for qualitative research and sociology of knowledge," Qualitative Sociology Review 8(2): 46-75.

Keller, Reiner. 2017. "Has Critique Run Out of Steam?-On Discourse Research as Critical Inquiry," Qualitative Inquiry 23(1): 58-68. https://doi.org/10.1177/1077800416657103.

Konings, Martijn. 2010. "The Pragmatic Sources of Modern Power," European Journal of Sociology / Archives Européennes de Sociologie 51(1): 55-91. https://doi.org/10.1017/ Sooo3975610000032.

Lamey, Andy. 2012. "A liberal theory of asylum," Politics, Philosophy \& Economics 11(3): 235-257. https://doi.org/10.1177/1470594X11416775.

McNevin, Anne. 2011. Contesting Citizenship: Irregular Migrants and New Frontiers of the Political. New York: Columbia University Press.

McNevin, Anne. 2017. "Learning to live with irregular migration: towards a more ambitious debate on the politics of 'the problem', Citizenship Studies 21(3): 255-274. https://doi.org/10.1080/13621025.2017.1281223.

Malachowski, Alan. 2013. "James's holism: the human continuum," in The Cambridge Companion to Pragmatism, ed. Alan Malachowski (Cambridge, UK: Cambridge University Press), pp. 36-54. https://doi.org/10.1017/CCO9781139022132.005.

Misak, Cheryl. 2017. "A Pragmatist Account of Legitimacy and Authority," in Pragmatism and Justice, ed. David Rondel and Susan Dieleman (Oxford, UK: Oxford University Press), pp. 295-308. https://doi.org/10.1093/acprof:oso/9780190459239.003.0018. 
Pappas, Gregory F. 2017. "Empirical Approaches to Problems of Injustice," in Pragmatism and Justice, ed. David Rondel and Susan Dieleman (Oxford, UK: Oxford University Press), pp. 81-96. https://doi.org/10.1093/acprof:oso/9780190459239.003.0005.

Peirce, Charles S. 1974. Collected Papers of Charles Sanders Peirce. Cambridge, Mass.: Harvard University Press.

Putnam, Hilary. 1981. Reason, Truth and History. Cambridge, UK: Cambridge University Press.

Putnam, Hilary. 2017. "Reconsidering Deweyan Democracy," in Pragmatism and Justice, ed. David Rondel and Susan Dieleman (Oxford, UK: Oxford University Press), pp. 249-264. https://doi.org/10.1093/acprof:oso/9780190459239.003.0015.

Rigney, Ernest G., and Lundy, Timothy C. 2015. "George Herbert Mead on Terrorism, Immigrants, and Social Settlements: A 1908 Letter to The Chicago Record Herald," The Journal of the Gilded Age and Progressive Era 14(2): 160-172. https://doi.org/ $10.1017 / \mathrm{S}_{1537781414000772 .}$

Rolin, Jan. 2005. Der Ursprung des Staates: die naturrechtlich-rechtsphilosophische Legitimation von Staat und Staatsgewalt im Deutschland des 18. und 19. Jahrhunderts. Tübingen, Germany: Mohr Siebeck.

Rorty, Richard. 1990. "The Banality of Pragmatism and the Poetry of Justice Symposium on the Renaissance of Pragmatism in American Legal Thought: Comments," Southern California Law Review 63: 1811-1820.

Rorty, Richard. 1992. "What Can You Expect from Anti-Foundationalist Philosophers?: A Reply to Lynn Baker," Virginia Law Review 78(3): 719-727. https://doi.org/10.2307/ 1073464.

Rorty, Richard. 2007. "Dewey and Posner on Pragmatism and Moral Progress," The University of Chicago Law Review 74(3): 915-927.

Welchman, Jennifer. 2010. “Dewey's moral philosophy," in The Cambridge Companion to Dewey, ed. Molly Cochran (Cambridge, UK: Cambridge University Press), pp. 166186. https://doi.org/10.1017/CCOL9780521874564.

Westbrook, Robert B. 1991. John Dewey and American Democracy. Ithaca, New York: Cornell University Press. 